\title{
ALGUNAS CONSIDERACIONES SOBRE LA POESÍA DE ALEDO LUIS MELONI ${ }^{1}$
}

Aldo Oscar Valesini

Estas consideraciones se centran en la poesia de Aledo Luis Meloni, que, de alguna manera, es como centrarlas en el poeta. Éste es un caso notable de coincidencia, de transparente nitidez entre el enunciador y el enunciado, donde la Verdad es un valor que atraviesa el ámbito de la "literatura" y se erige como paradigma de existencia.

Los objetivos propuestos son básicamente de carácter descriptivo, y consisten en proporcionar una visión -tanto sincrónica como diacrónica- de su obra, rescatando de la primera, los temas centrales de su poética, y de la segunda, un bosquejo de la evolución mediante la identificación de criterios y categorias pertinentes.

Ello no obsta, como se advertirá, para formular algunas hipótesis de carácter general, con el propósito de esclarecer teóricamente la obra de Meloni. Por una parte, sostenemos que la constitución del universo poético se logra como construcción imaginante sostenida en el espacio de San Antonio. Es éste el continente de los diversos temas y de la sustancia poética tal como se desarrolla en toda la producción.

También creemos que la evolución de su poética manifiesta un cambio en el sentido de su posición frente a la historia. A una actitud en la que prima la visión de la naturaleza y del hombre más allá de las vicisitudes circunstanciales, gradualmente se la sustituye por una postura de lucha mesurada, de crítica sagaz, de ejercicio responsable de la condición histórica del hombre que intenta, a través de la creación estética, definir una postura, arraigar su palabra en la tierra con la que se identifica y a la que recurre como sustento estable.

Al mismo tiempo, se puede afirmar que la textura fónica, metafórica, lingüistica de los poemas, así como las estructuras métricas, ritmicas y retóricas manifiestan una notable uniformidad, reforzada deliberadamente por la permanente revisión y corrección a que el autor somete toda la obra, a través de un paciente enfrentamiento con la palabra, que es una actitud metafísica: definir el ser del lenguaje es una manera de penetrar su propio ser, según lo manifestaba Heidegger, cuando se refería a la lingüisticidad del ser. Esta actitud involucra un desdoblamiento del poeta, una relación especular en la que el sujeto es a la vez objeto, en la que el yo lucha, se confronta, dialoga con las voces de los poemas hasta lograr encontrar un equilibrio precario, como el de toda creación:

\footnotetext{
${ }^{1}$ Este trabajo reúne parcialmente algunos capítulos de la Tesis de Licenciatura "La obra poética de Aledo Luis Meloni", dirigida por los profesores María Agustina Alasia de Bosch y Orlando J. Genó, y que comenzara a gestarse con la orientación fervorosa de Alfredo Veiravé.
} 


\section{Música}

(...)
Tuve después, en vez del metal, la palabra,
que es más rebelde que el metal más duro.

También a ella quise darle forma; manejarla a mi antojo;

hacerla florecer como un lapacho.

Pero no pudo ser.

De los poemas que escribi ninguno suena en mi corazón tan dulcemente como la música del yunque y del martillo.

(...)

(T.A., p. 27)

En su obra convergen el significado con los artilugios lingüisticos empleados para comunicarlo, en una conformidad admirable entre enunciación y lexis, entre 10 que se dice y el modo de su decir. La actitud vital del autor acerca de la literatura y del arte es transfundida, de hecho, a su poesia, lo cual permite al lector moverse libremente entre poesia y poética. La posibilidad de que se plantee un conflicto entre ambas no parece surgir nunca. El "contenido" poético y la "forma" poética están tan perfectamente unidos en la obra de Meloni, que resulta imposible objetar nada contra el valor de su poesía en nombre de una posible divergencia entre "pensamiento" y "poesia". Semejante divergencia es inconcebible porque se admite que Meloni afirma, a lo largo y a lo ancho de su poesía, la verdadera esencia de la poesía como la verdad de esta esencia.

Por otra parte, si todo lenguaje habla acerca del lenguaje, entonces el modelo lingüístico paradigmático es el de un ente que se confronta consigo mismo. Nuestro autor ahonda la cuestión con insistencia, con la certeza de que el poema es básicamente un objeto verbal y que los temas contribuyen a sostener una dialéctica que en definitiva se construye sobre la palabra, una palabra trascendente que no es una mera mención, sino una palabra que "es" en cuanto capaz de llegar a una identificación sustancial con el hombre. Sujeto y lenguaje confluyen en el verbo.

\section{Detrás de las palabras}

Detrás de las palabras amor, sueño, esperanza, estoy yo;

detrás de las palabras duda, temor, angustia, estoy yo; 
detrás de las palabras odio, venganza, envidia, estoy yo;

detrás de las palabras culpa, arrepentimiento, estoy yo.

Estoy allí porque detrás de la palabra hombre, estoy yo.

Y sobre todo estoy detrás de cada una de las siete letras que forman la palabra corazón.

(T.A., p. 23)

\section{El poeta terrestre}

"La forma pura del verso/ solo y en silencio labra;/ que nadie sepa el esfuerzo/ que cuesta cada palabra. "(PyC, p. 72)

Meloni publicó su primer libro, Tierra ceñida a mi costado, en 1965, a los 53 años.

Alli recopila una treintena de poemas escritos durante un lapso de aproximadamente veinte años, mientras ejercia la docencia en la zona rural del sudoeste chaqueño.

En 1956 se trasladó a la ciudad de Resistencia por razones de trabajo, como Inspector de Escuelas Nacionales, hasta su jubilación.

Desde aquella primera edición ha publicado otros doce volúmenes de poesía, los cuales han sido reeditados en su mayoría, incluso reiteradamente. Su obra testimonia una notable influencia de sus años de docencia rural, en lo que se refiere al desarrollo de una estética donde prima lo sensible, una poética de la proximidad. La actividad cotidiana ha recortado un universo de experiencia al cual, como dice Jean Guitton, "le ha comunicado la dignidad de ser el mejor" i.

La convivencia con un mundo extraño, hostil, con una naturaleza casi en bruto y el contacto con tipos humanos singulares, poco identificables con el joven pampeano, son algunos puntos de referencia que definen esta etapa, (esta suerte de "residencia en la tierra"), en la que pueden señalarse datos significativos en cuanto a la definición de su vocación literaria:

Alli se produjo su verdadera toma de conciencia sobre la poesía, cuando, un poco por azar, leyó unos versos de Antonio Machado. Desde entonces, orientado por el poeta de Castilla, por Horacio Quiroga y otros, delimitó un ámbito de lecturas que, aunque reducidas, iluminaron su vocación latente.

Así como Montaigne exaltaba las virtudes de la lectura como instrumento eficaz para lograr la premisa renacentista del "conócete a ti mismo", Meloni, intuitivamente, se fue rodeando de un espacio de lectura donde sustraerse de 10 
cotidiano, para mantener el siempre misterioso diálogo de un espíritu con la voz de un autor que, ilusamente, creemos que nos ha escrito.

La misma soledad del entorno le ofrecía la opción: el paisaje, los libros. El no vio la antítesis; supo leer en ambos: "A veces en las tardes una cara/ nos mira desde el fondo de un espejo;/ el arte debe ser como ese espejo/ que nos revele nuestra propia cara". (PyC ,p. 843). En esa operación misteriosa fue gestándose una sensibilidad atenta a lo minúsculo, a lo cotidiano, una actitud de amor al hombre, que es valiente protagonista de aquella escena del mundo. El contacto humano en cuanto significa comunicación estaba también en buena medida limitado, ya que los colonos europeos hablaban apenas el español: la verbalización de su horizonte de experiencia necesitaba otros canales.

Otra dimensión de la soledad está dada por la apertura del hombre hacia si mismo. Alli, en la profundidad, en la verdad de sí mismo encuentra el canto, que en sus coplas adquiere el significado de "poesia", estado puro del espiritu que aflora gracias al milagro de la melodia o de la palabra.

\begin{abstract}
La vez que anduvo más solo creó el hombre la guitarra; las penas, que saben mucho, le enseñaron a pulsarla.
\end{abstract}

(PyC, p.97)

Tales ejes de referencia definen en el hombre una marcada dependencia de lo externo. La inserción psicológica de un espacio no tanto en el mundo de los demás hombres, sino en el mundo de la naturaleza, en sus matices, en el tacto. Su instalación en la Colonia de San Antonio to percató inmediatamente de la nueva perspectiva física del horizonte, diferente de la de su lugar natal.

Había frecuentando las visiones de la pampa porteña, donde el horizonte desconoce todo obstáculo que le impida enfrentar el infinito- (¿Quién no recuerda las descripciones de Guillermo Enrique Hudson?). aquí su mirada encontraba un límite, se complacía en observar las cambiantes formas del crepúsculo recortadas sobre los árboles: el hombre no se halla completamente desguarnecido; hay un lazo que lo amarra al mundo, establece los límites, ordena la mirada, enciende la imaginación: "La muralla del árbol estrecha su horizonte:/ la capilla, la escuela, y en torno, algunas chacras", nos dice en el poema "Colonia de San Antonio" (PyC, p.24).

A partir de esta forma de extrañeza que le transmite la perspectiva, observa el mundo y lo descubre con inocente asombro. Era esta aventura una nueva búsqueda de horizontes, con los sentidos alerta, los una permanente reconstrucción de los esquemas, una re-estructuración de la "enciclopedia". En la naturaleza, la soledad se minimizaba y constituia la chance para intensificar la comunicación profunda que se estaba produciendo entre su alma y el alma de la terra mater: "...caminos para andar de sueño en sueño.l de soledad en soledad/ de canto en canto; ..." (PyC, p. 16).

Sin dudas, esta etapa de conocimiento sería eminentemente sensorial; todo descubrimiento se concreta en el momento en que se unen sujeto y objeto en el todo de la percepción, y asi lo refleja su poema: "Amanecer": 
En el monte despiertan las charatas

y en el cielo se duermen las estrellas.

Camino del Palmar, pasa un arriero

silbando una vidala soñolienta.

Se diría que a cuestas del silbido

lleva el cadáver de un millar de leguas.

Un arado inaugura la mañana

en su prisión rectangular, la melga.

A espaldas del labriego queda el surco

con avidez de lluvia y sementera;

Y una bandada -pluma y voz- de pájaros

su corazón abierto picotea...

(PyC, p.14)

La obra total de Meloni mantiene una dependencia permanente con respecto al espacio: la Colonia de San Antonio. Una cosmogonia se afirma a partir de la toma de posesión en el espacio mítico: el ómphalos, el axis mundi, lugar sagrado de convergencia de los tres planos del universo: el cielo, la tierra y el infiemo. Siempre hay algún signo que indica su existencia y se transforma en sacro: "Atardecer"

Sueña en la rama gris de un árbol seco una viudita de carbón y nieve.

Su alhaja viva el árbol seco luce mientras la tarde, abandonada, muere.

Un silencio de asombro, de misterio. en su magia inefable al mundo envuelve.

Por un instante el corazón del mundo es la viudita de carbón y nieve.

(PyC, p.23)

Un soporte geográfico que trasciende el plano conceptual hasta proporcionar modelos estructurales de su obra (¿Acaso la copla, con su brevedad, su escasez de vocabulario, su sequedad de adornos, no es una traducción legítima de un paisaje precario, tosco, despojado, y a la vez capaz de impresionar al hombre con un cardo, o con el aroma de las tuscas?).

Gran parte de su obra está sostenida en el campo semántico de este espacio. Constituye una versión del paisaje, una aventura del lenguaje, animada por el lirismo logrado en el recogimiento y en la cautela del lenguaje.

Poesía que se gesta en la mirada, en la voz, en el olor; poesía que sobrevive y retorna en una memoria dirigida permanentemente hacia aquella lejana tierra de San Antonio, con la fidelidad del amante, con la sed del peregrino que bebe en su memoria el agua ofrecida tiempo atrás, en una casa desconocida. 
Gran parte de su obra está sostenida en el campo semántico de este espacio. Constituye una versión del paisaje, una aventura del lenguaje, animada por el lirismo logrado en el recogimiento y en la cautela del lenguaje.

Poesía que se gesta en la mirada, en la voz, en el olor; poesía que sobrevive y retorna en una memoria dirigida permanentemente hacia aquella lejana tierra de San Antonio, con la fidelidad del amante, con la sed del peregrino que bebe en su memoria el agua ofrecida tiempo atrás, en una casa desconocida.

Asi, Meloni, por distintas puertas, con distintos rostros, retorna infinitamente a este microcosmos, hasta el punto de cargarlo de significaciones insospechadas, pero manteniendo constantemente la fidelidad a la esencia de cada cosa. El paisaje se asimila, se deforma, habla, desaparece en busca del rocio, pero vuelve puntualmente al amanecer del poema. Nos muestra que, por la magia de la poesia, podemos descubrirnos plurales frente al mismo objeto. "Yo soy un hombre de la tierra", afirma el poeta.

San Antonio es la fortaleza interior que reelabora permanentemente en la palabra con variados tonos: melancólico, agradecido, añorante, siempre con un regocijo apenas visible, hondamente sentido. Es el poeta de la Colonia de San Antonio, y con ello no menguamos la universalidad semántica ni la validez estética de su escritura, sino le otorgamos una consistencia sustancial. La Colonia es el prisma a través del cual se proyecta la totalidad de la experiencia de un ser humano, purificada por la emoción y la sensibilidad. Es "su" mundo.

Una poética, desde el punto de vista de la sustancia, necesita un punto de apoyo, algo semejante a un cuadrante en el Zodíaco del Mundo para construir un cosmos perdurable. "Me animo a decir que no hay una poesía perdurable que no instaure en la cultura de un pais, formas nuevas de la tradición y de la conciencia de una sociedad; que toda literatura comporta una conducta, una cosmovisión y una ideología, y que el mapa de la provincias argentinas se ilumina con nombres muy queridos. Son los poetas que vivieron y dejaron su poesia en el viento de pequeñas ciudades y pueblos, con las raices profundamente enterradas en el humus de un subsuelo que sustenta a la América invisible, dentro de una América Latina que es cada vez más visible en el mundo.", afirma Alfredo Veiravé.ii

La intimidad de la mirada, la pulsación intuitiva reduce la complejidad del universo, la ordena a partir de los parámetros del silencio interior hasta lograr la armonia correcta, la palabra precisa: "La verdadera poesía no brota de la sensación, pero es preciso que la sensación abreve las tierras oscuras de la memoria. Es preciso que el ser entero, en comunicación con todo el universo, participe en la elaboración natural de la poesía más desencarnada en apariencia". iii

Esta primera etapa en que se unifican el mundo exterior y el mundo interior, de acuerdo con el lugar preeminente que ocupa la imagen, está definida tanto cronológica como sincrónicamente. Potebnia y sus discipulos formalistas consideraban a la poesia como una manera particular de pensamiento: el pensamiento por medio de imágenes.

Según la naturaleza semántica de las imágenes, hay un predominio de lo externo, a pesar de lo cual se mantiene integramente el equilibrio entre sensibilidad y 
subjetividad. A ello debe sumarse la acción de la palabra que al nombrar, debe generar ese doble movimiento simultáneo: creativo y destructivo del ritmo único.

Armonia que abarca al sujeto y al objeto en el espacio mágico de la palabra poética: "Escribir es hacerse eco de lo que no puede dejar de hablar. $Y$ por eso, para convertirme en eco, de alguna manera debo imponerle silencio. "iv

El mismo Blanchot, al referirse a la imagen, habla de la fascinación, como la imposibilidad de dar sentido a la naturaleza sensible del objeto, puesto que el sujeto se encuentra en ese territorio ambiguo que no es real y que se sitúa en la profundidad existente detrás de la imagen.

Según esta idea, la imagen, en la primera etapa de la obra de Meloni, es todavía sólida y, aunque tal espacio de "fascinación" se insinúa con claridad, no alcanza la dimensión que tendrá en sus últimas etapas.

\section{Intermedio: la copla.}

La poesía de Meloni se ha caracterizado desde un comienzo por algunos rasgos: mesura verbal, equilibrio entre la imagen y la palabra, economía de recursos. Poesia que trasluce un cierto pudor, palabra que ve la luz en una grieta meridiana de equilibrio, situada en un espacio que dista tanto del intimismo confesional como del desborde de la pirotecnia verbal. En estos límites, el poema aguarda dispuesto a estallar al menor intento de contacto. Con su lenguaje preciso, claro, capaz de traducir de la manera más directa y efectiva el pensamiento, se produce un movimiento (¿premeditado en el discurso, inconsciente del lector ?) que desemboca en una forma poética ajustada estrechamente al tono del espíritu. Una forma latente ya en sus primeros poemas, que se hace explicita en la parte denominada "intermedio" de su segundo libro, Rama y Ceniza : la copla.

Cabe aquí una aclaración. El sentido con que utilizamos el término "etapa", no depende de un criterio rigurosamente cronológico; más bien designa a las "formas poéticas" recurrentes, a las "dimensiones" formales y conceptuales que se le pueden asignar a su lenguaje; los diferentes cauces que la sensibilidad del poeta ha ido descubriendo y estableciendo en la expresión y a los que retorna permanentemente.

En consecuencia, no es contradictorio admitirlas superpuestas, animando una pluralidad de códigos cuya convivencia conforma un correlato del lenguaje poético y cuya síntesis configura una poética.

La copla es la justa expresión del espíritu de Meloni, columna vertebral de su obra que ofrecía indicios ya en Tierra ceñida a mi costado: "Paloma":

Llevo una paloma triste

prisionera en mi pupila:

la sombra que dibujaba

su mano en la despedida.

(PyC, p.22) 
Señalamos a ésta como una instancia importante de la poética del autor porque está enraizada con la visión total que manifiesta en su producción. Para utilizar prestado un término de la narratología: a través de ella, Meloni "focaliza" la realidad. Manifiesta, si no una evolución, al menos una apertura que ha permitido la incorporación de elementos que enriquecieron el universo poético.

La consideración de esta etapa como "intermedia", se apoya en el hecho de que el corpus total de las coplas (que incluye: "Intermedio", de Rama y Ceniza, Coplas de Barro, Como el Aire y el Día, "Pausa", de Costumbre de Grillo, "Coplas de ayer" de Umbral del Silencio "Canciones del amor ingenuo" de La luz que uno amaba y "Notas al margen" de La otra mirada) contiene una actitud dual, cuyas aristas son: la descripción, el pasaje, el detalle minúsculo impregnado de emoción poética:

Taumaturgia de la tierra:

bajo la hoguera del sol

la alfalfa verde y mullida

y el algodonero en flor.

(PyC,p.17),

y por otro lado, una actitud reflexiva que requiere una toma de distancia con respecto a la realidad, una afirmación valorativa que trasciende la experiencia y con frecuencia roza lo metafísico:

\section{La piedra se parte a veces \\ aunque nadie la golpea; \\ es cuando le estalla dentro \\ la amargura de ser piedra.}

(PyC,p.86).

Si no fuera cruel decirlo,

diría que están de más

árbol que ya no da sombra,

corazón que no ama ya.

(LOM, P. 24)

Aunque no es posible aislarlos de la totalidad de su obra (lo cual, sin dudas, pondría en evidencia la artificiosidad de la forma artística), al menos en ella aparecen precisados y ordenados de manera unitaria tanto los rasgos formales como temáticos que guiaron al poeta desde el comienzo.

Roman Jakobson afirma que "la obra poética debe, en realidad, definirse como un mensaje verbal en el cual la función estética es la dominante"v. La función de la dominante representa, en su opinión, el elemento focal de una obra de arte, el que "gobierna, determina y transforma los otros elementos. Es ella la que garantiza la cohesión de la estructura". Puede hablarse de la "dominante" de un autor, como de la "dominante" del arte de una época.

Al revisar la obra de Meloni, no dudábamos en afirmar que la "dominante" es la copla. Es el ordenador estético de toda su producción; el que ha establecido una norma que la intuición sostuvo y que debe ser puesta en juego como patrón para 
descifrar las claves de su poética. En ella se encuentran "los elementos especificos que determinan el rol y la estructura de los demás constituyentes." Agrega Jakobson que la organización de los elementos poéticos establecida por la dominante es exterior a la esencia misma de la obra, y que atiende a la estructura del poema en lo concerniente a su textura fónica, sintáctica y sus imágenes. Incluso podemos comprobar que tales caracteres han sido señalados conscientemente por Meloni: "Vuelvo a menudo y con emoción a su obra -se referia a la de Jorge Luis Borgesporque ahonda sobre todo en los poemas, en vetas profundas y trascendentes que llegan a la rafiz misma de la vida del hombre y a su inquietud metafísica.vi

\author{
Coplero soy, alma adentro: \\ una manera de ser; \\ aunque en la copla me encuentro, \\ siempre me vuelvo a perder. \\ Copero iluso que busca \\ dejar desnuda en la arena, \\ por la suerte de una copla, \\ la cicatriz de su huella.
}

(PyC,p.80).

En este breve poema, "Coplero", manifiesta, en primer lugar, la naturaleza intima de su relación con la copla (que en su obra adquiere frecuentemente la expresión de "canto"): "una manera de ser", lo cual alude indudablemente a una actitud que lo compromete como ser humano. Esta perspectiva vital se manifiesta en una incesante búsqueda, no tanto exterior, sino más bien interior: "Llevo una copla en el alma/ igual que un grillo nochero;/ yo sé que es muy poca cosa/ pero me basta con eso." (PyC,p.61). Inmediatamente alude a un concepto reiterado con frecuencia: el laberinto, que se asocia a la función lúdica del arte. En la segunda estrofa está implícita la valoración de lo afirmado; la reflexión adopta una postura "objetivan, se alude a sí mismo con cierto humor ("coplero iluso") y hace referencia de manera implícita a uno de los temas constantes de esta fase: el tiempo, la imposibilidad de atraparlo, detener su fluir en una búsqueda de eternidad, aunque más no sea en la forma del recuerdo en la memoria del pueblo.

\title{
3. La evocación del poeta.
}

Gastón Bachelard señala una distinción entre las fuerzas imaginantes del espiritu: una, que expresa una búsqueda pura del ser, valiéndose de una renuncia a aquellos dones verbales innecesarios para tal persecución; la otra es la que manifiesta su placer ante la novedad de los espectáculos fastuosos: los colores, las formas, los sonidos impactantes. Gusta de 10 pintoresco, de 10 inesperado y sorprendente. Desde el punto de vista filosófico, tendriamos dos causas de la imaginación: una que alimenta la causa material; otra que alimenta la causa formal. 
Esta dualidad ya habia sido señalada por Antonio Machado en una nota enviada a Gerardo Diego, en 1931.vii En ella afirmaba que "La poesía moderna (...) viene siendo la historia del gran problema que al poeta plantean estos dos imperativos, en cierto modo contradictorios: esencialidad y temporalidad. El pensamiento lógico, que se adueña de las ideas y capta lo esencial, es una actividad destemporalizadora. Pensar lógicamente es abolir el tiempo; suponer que no existe, crear un movimiento ajeno al cambio, discurrir entre razones inmutables. (...)". Cuestionaba asi la tendencia a la poesia metafísica que se despreocupa de lo emotivo en el plano conceptual y de los recursos en el nivel formal.

\title{
Laberinto
}

\author{
A veces \\ vuelvo a un puerto de mástiles oscuros, \\ de boyas encendidas \\ y de lanzas de luz temblando en la corriente. \\ Mientras el agua con sus dedos numerosos \\ le acariciaba el flanco dulcemente, \\ la ciudad se miraba \\ en el espejo fugitivo; \\ y abría sus ventanas \\ al aire puro que llegaba desde el río, \\ entre el aroma adivinado de los juncos \\ y el lejano rumor del viento enlos alisos.
}

$A$ veces

vuelvo a un puerto de mástiles oscuros;

a una ciudad que se miraba

en el espejo fugitivo...

En ella anduvo

mi corazón enamorado un día,

como en una divina encrucijada,

como en un encantado laberinto.

(Inédito, 1997)

En Meloni hemos presenciado un notable acercamiento a lo terrestre como espacio para animar la voluntad del ejercicio creador.

Imaginación significa acá, un "ir hacia" los objetos, en un movimiento que contiene la percepción, aunque la supera en el sentido de que la imagen tiene la capacidad de enriquecer lo dado por la experiencia.

Aparte de las formas de manifestación a través de la inmediatez de la imagen, encontramos la abstracción como forma de trascendencia, aunque 
momentánea con respecto a la realidad. La reflexión torna el poema en una detención meditativa:

$$
\begin{aligned}
& \text { Cada camino, si es claro, } \\
& \text { lleva a Dios; } \\
& \text { más yo no puedo seguirlo } \\
& \text { dentro de mi corazón. } \\
& \text { (PyC,p.39) }
\end{aligned}
$$

En el transcurso de la obra podemos apreciar una leve toma de distancia con respecto a la dependencia del entorno y una delimitación de la dirección de la voluntad poética: la primacía del yo; la intimidad, que si bien necesita abrevarse en lo externo, recompone las formas y sustituye los datos sensibles por impresiones donde predomina lo afectivo. La fidelidad es mantenida en lo que respecta a la dinámica interior, mientras esto implica una suerte de desintegración de la materia real, llámese a esto memoria, subjetividad, libre asociación, evocación.

Es evidente que la sustancia (los objetos del mundo de la obra de arte) residen y encuentran su razón de ser en el sujeto. Su historia se explica en la experiencia. Están acumulados soportando el peso del tiempo que los vincula entre sí, los ordena, jerarquiza y les otorga la consistencia propia del calor espiritual que dicta la intuición.

La diferencia visible entre la primera y esta etapa, radica en el sentido otorgado a la presencia de los objetos. Mientras en principio el mensaje era inmanente a ellos, ahora encontramos una instancia intermedia entre el signo y su referente: la reflexión, ese espacio donde la emoción, la vivencia, neutralizan la materia en bruto de la sensación.

$Y$ es precisamente gracias a esta manera de abordar la realidad como el poeta logra la sintesis capaz de trascender la mera experiencia particular. La reflexión es un descubrimiento de lo universal, como lo expresa Marcel Raymond: "Mas aunque se trate de sumergirse en la vida o de superarla, de aceptar o negar la duración, la condición primera -se refiere al impulso poético-consiste en olvidarse, en borrar los límites del yo, en adentrarse más allá del lirismo personal. "viii La referencia a "borrar los límites del yo", no alude a la renuncia de lo subjetivo, sino a la apertura que, a través de lo subjetivo, debe ser capaz de establecer vínculos entre la experiencia del poeta y la de otra conciencia, aunque alejada en el tiempo, ligada y próxima en lo vital. Paul Valéry afirmaba que "...es un error contrario a la naturaleza de la poesía (...) el pretender que corresponde a cada poema un sentido verdadero, único y conforme o idéntico a algún pensamiento del autor...".ix

Esta obra (sus mecanismos profundos de construcción, su transfiguración del universo material a través de la palabra), responde definidamente a una intención consciente del autor. Meloni no deja librada al azar su tarea. La asume responsablemente con el cuidado de un orfebre. Así interpretamos las permanentes correcciones de su obra total con un afán incansable de hallar la justa palabra para nombrar lo intuido: "Trabajosamente/ empujo mi canto:/ sueño a sueño,/ vocablo a vocablo." (PyC,p.44). 
El poeta se mantiene fiel a la temática; también la forma se reitera. EI tránsito, casi imperceptible, se da entre dos actitudes que corresponderían, una "al hombre que mira", otra, "al hombre que medita", lo cual confirma la característica clave de su evolución lírica como una manifestación auténtica de la preocupación existencial del sujeto. Por diversas razones (éticas, estéticas, semánticas, etc.) la poesía y la vida de Meloni se confunden; son atravesadas por las hondas venas de un humanismo esencial.

\author{
Tierra del oeste, al sol \\ $y$ al viento crucificada, \\ donde anduve haciendo huella \\ creyendo que hacia patria; \\ donde vi dormir la fiebre \\ de la semilla en las chacras, \\ y hacer silencio a la seca \\ para que no despertara; \\ o arder una siesta al rojo \\ todo el verdor que uno amaba, \\ y a un hombre de un algarrobo \\ colgar su desesperanza... \\ Tierra del oeste, al sol \\ $y$ al viento crucificada, \\ yo llevo como una herencia \\ tu misma sed en el alma.
}

(PyC.p.151).

\title{
LA MATERIA EVANESCENTE
}

Gastón Bachelard $x$ elabora un análisis minucioso de la materia poética. Su propuesta consiste en considerar la imagen como expresión virgen de las fuerzas imaginantes del espíritu, las cuales pueden insertarse en un esquema constituido por los cuatro elementos fundamentales de las mitologías: el aire, el agua, el fuego y la tierra.

La imagen, como una forma natural requerida por la materia, es responsable de activar la subjetividad, sorprender el espíritu, dar peso a la emoción y movilizar el intelecto.

En la obra de Meloni, si bien de manera sutil, se observa una transformación de la materia poética: una gradual transición que tiene como punto de partida la apertura del hombre al objeto (el paisaje); de alli su mira se desplaza hacia la palabra (el verbo); y finalmente de ésta al silencio (la búsqueda de otro código). Dicha transformación puede incluso detectarse en algunos títulos de sus libros respectivamente: Tierra ceñida a mi costado (1965), La palabra desnuda (1980), Umbral del silencio (1983), La luz que uno amaba (1987), Antes que sea nche (1990) y La otra mirada (1992). 
Progresivamente el poeta fue reduciendo la distancia entre el exterior y lo interior, en un buceo intuitivo que psicológicamente traduce sus mecanismos de relación con el mundo y consigo mismo aprehendidos en la revelación poética. En el principio es evidente la imagen de la naturaleza en su constatación empírica; luego, las transformaciones del objeto por medio de la abstracción, de la reflexión que es proyección de lo interior sobre el otro.

El cambio más notable se operó a nivel de la sustancia de la imagen: desde una concepción alimentada en lo visual, materialidad que se corporiza en el color, la luz, las formas, afecta nuestros centros nerviosos y nos conmueve al abandonamos, solos, en el paisaje; desemboca en un repliegue obsesivo de la emoción sobre la experiencia interior, a través de los matices de la evocación. El tema y la actitud están implicados, se contienen al punto de convertirse en una imagen total. El animismo impregna los objetos del mundo, los ordena prolijamente en la alcoba de la memoria.

\section{Viejo poema.}

Cuando te evoco, madre, me parece que todo recupera la forma del ángel y su voz;

y que voy de tu mano, desandando el asombro: los antiguos caminos que venían de Dios.

$Y$ ia palabra se me vuelve niña: paloma, grillo, lámpara de amor;

y descubro en tus ojos el corazón del mundo abierto a la esperanza como una achira en flor.

(PyC,p.136)

Desde una perspectiva temática se aprecia la permanencia de los campos semánticos, aunque cronológicamente, el tono y los elementos de la enunciación definen modalidades diferentes. Distancia que puede situarse en la dialéctica entre el sujeto y el objeto poético, y que se caracteriza por definir una actitud hondamente enraizada con la concepción poética, capaz, en consecuencia, de convertirse en rasgo de su estética.

La cuestión, en síntesis, se puede plantear en los términos con que Mikel Dufrenne establece el mecanismo de la experiencia estética desde el encuadre fenomenológicoxi: la oposición entre realidad poética y realidad empírica.

La consideración diacrónica de la obra poética de Meloni nos permite advertir que se ha operado un distanciamiento entre lo vivido y lo pensado, el cual implica una distinción cualitativa: lo que aparece en la conciencia poética como imagen no es la reproducción del objeto tal como es captado sensiblemente, sino la imagen esencialmente anímica, que reproduce los recuerdos, las vivencias perdurables del espiritu que lo constituyen íntimamente, observable en la enunciación. 
En una distinción entre "sensibilidad" (que sería la capacidad del sujeto para "abrirse" al objeto, aptitud para acogerto en su interior; cualidad que alude más que nada a las capacidades fisiológicas de los centros nerviosos) y "subjetividad" (como la aparición en la conciencia del objeto percibido, enriquecido con todos los "saberes", sensaciones, voliciones, sentimientos, datos en general que nuestra experiencia anterior pueda aportar en la imagen) se puede afirmar que la mediación subjetiva se ha acrecentado hasta ordenar el mundo poético, no según las condiciones dadas en la realidad objetiva, sino de acuerdo con un paradigma anímico; y que tal mediación se caracteriza fundamentalmente por la presencia de un discurso "desde si", y en general, por el carácter evocativo de su postrera producción (la búsqueda de lo perdido).

Gradualmente, el poeta ha encontrado en si mismo la densidad material y el espacio virgen necesarios para sustentar su obra; actitud poética que es al mismo tiempo actitud vital: la búsqueda del pasado, el "regreso", se cumple en la única dimensión posible: a través de la memoria

En la flor que se deshoja

en la ceniza del día halla su miel la poesía

su miel y su paradoja.

(PyC,p.35).

Es posible tomar como punto de partida su "paradoja" en calidad de elemento estructurante de una postura manifiesta, y a la vez como definitoria de algunos de sus grandes temas. ¿Qué origen atribuimos al ensanchamiento de su interioridad mediante incesantes diálogos del hombre consigo mismo, y que genera una profundización intelectiva y sensible a la vez, que se hace visible ya desde coplas de Barro?

Tierra Ceñida a mi Costado es una luminosa celebración de un mundo al que se siente unido a través de la tierra, en que halla un fundamento sólido, vínculo de unión con la realidad. Así lo vemos ya en su poema inicial:

Para escuchar el latido

verdadero de mi sangre

voy, tierra, voy al encuentro

de tu pulso innumerable

(...)

(PyC,p.7)

Este "ir al encuentro de la tierra" requiere una actividad sutil de los sentidos, los cuales aportan la materia prima a este observador agudo y paciente que adopta la misión de reescribir en imágenes el paisaje. "El arte dice, expresa plástica, musical y verbalmente a través de esquemas, figuras y colores lo que es el mundo en el momento mismo en el que sus ritmos vibran. Se trata de aquello que he llamado la 'poeticidad' del mundo."xii La voz del poeta se explicita en el sentido, en la emoción. La intimidad del espíritu se añade a la percepción pura: 


\section{Olvido}

Mientras el agua, hermana del crespín y del grillo, con su estribillo a cuestas, lentamente se pierde, la luna deja, pródiga, la seda de su ovillo abandonada al raso, en la gramilla verde.

En la rama del árbol que decora el paisaje, un pájaro vacía la aljaba de su anhelo.

Nadie piensa en la sombra. Nadie piensa en el viaje.

La vida es esa nube detenida en el cielo.

(PyC,p.15)

$Y$ en tal celebración del mundo poético, de la que la palabra es mediadora y artífice, el presente de la imagen confirma la apertura de la sensibilidad frente a una realidad que se le entrega en una evidencia transparente:

\section{Sembrador}

Sobre la tierra herida de setiembre el sembrador es una mano abierta.

A la orilla del alba, como un rito su ademán inaugura el tiempo de la espera.

(...)

$$
\text { (PyC,p.18) }
$$

Esta actitud, en general, es bastante diferente de la que manifiesta en los poemas de Umbral del silencio, donde retoma el mismo tema:

\section{Los sembradores}

Soñaban con la paloma y la reja. Nada más.

(...)

Eran de buena madera los hombres de allende el mar.

$$
\text { (U.S.p.33) }
$$

Una de las dimensiones en que podemos interpretar esta separación de lo exterior corresponde a la adquisición de una nueva noción del concepto de libertad, traducida en un mecanismo estético, como es la fidelidad a las formas interiores antes que a los objetos delimitados, percibidos por los sentidos.

La dialéctica entre objetividad-subjetividad se resuelve hacia el final, cuando la memoria asume una función unificadora. 
El poeta se ha deslizado progresivamente hacia si, ha ocupado un nuevo punto de vista para abordar el mundo diario y desentrañar su sustancia poética.

Así descubre que, misteriosamente, el objeto es susceptible de mutaciones inesperadas, que incluso puede esfumarse, pero que pese a la desaparición aún era posible la emoción poética, lograda a través de la "re-vivencia" que implica el nombrar lo ausente. La poética de Meloni tiende a constituirse en una búsqueda de lo perdido definitivamente sin encono, sin violencia.

En este punto, la valoración de la palabra adquiere una importancia decisiva: el poeta vislumbra el origen de los objetos, encuentra el misterio de la percepción poética en la evocación. El vínculo entre el presente y el pasado se establece merced a la palabra: en este otorgar presencia el ente por obra de la palabra, que es un "recrearlo" en el sentido míticoxiii, halla el espacio necesario para acercarse a si mismo.

\section{Mi pueblo}

En un vía muerta, en su ayer detenido está mi pueblo: el de mi huella y de mi sombra; el de mi amor y de mi olvido.

Cuando mi corazón quiere soñar, lo nombra.

(PyC,p.143).

De modo paralelo a esta creciente confianza en la palabra, detectamos una tendencia hacia una mayor subjetividad: un despliegue del objeto en cuanto es un núcleo que moviliza psíquicamente las asociaciones y la valoración del mundo en calidad de referente del paisaje interior.

El acto creativo se independiza en gran medida de lo externo como materia significativa de lo poético. Lo esencial es nuevamente el presente, pero ahora en la medida en que representa el contexto donde se sitúa el poeta (enunciación); y en lugar de poeta, estaríamos tentados de decir el eje sensible del hombre; el espejo que proyecta lo pretérito sobre el ahora; el presente que está contenido en la emoción, en la piel profunda con que recubre los objetos que han roto las distancias entre el exterior y el interior.

\section{Las tuscas}

$A$ veces llega

de San Antonio

la memoria querida de las tuscas.

Las tuscas se abrasaban

a los caminos

con un amor humilde y para siempre. 


\begin{abstract}
En los atardeceres de hogueras encendidas ellas abrian como un verde pebetero el corazón enamorado.
\end{abstract}

Su aroma fuerte y áspero subia entre la polvareda que levantaban las volantas rusas.

La polvareda se quedaba en el aire suspendida como una niebla cálida;

y entre el aroma de las tuscas uno escuchaba y comprendía las voces enigmáticas, en clave, de la tierra.

$$
\text { (LL..., p.145). }
$$

$Y$ en este movimiento hacia adentro que tiene por finalidad desentrañar el mundo a través de la experiencia virtual de la memoria, está implícita la concepción de que la verdad reside en su interior. Algunas corrientes epistemológicas, surgidas de y orientadas por los descubrimientos de Albert Einstein, insisten en el hecho de que la verdad no es la percepción de un único modo de ser del mundo, sino una transacción relativa que admite la validez de las múltiples percepciones subjetivas de la realidad. Esta tesis, que ya estaba presente en el cubismo, establece una paradojica concepción del sujeto: por un lado lo avala un subjetivismo a ultranza en el hecho de validar la experiencia personal como el correlato "verdadero" del objeto; por otro, en pos de un "objetivismo" ilimitado, niega la idea de "cierre" de la verdad, parciales como los modos de ser (válidos) de lo denominado realidad.

Creemos que en Meloni se cumple esta adhesión y se convierte en un valioso soporte inconsciente de la génesis de su obra:

\title{
Presencia
}

Aunque el dia, que es frágil, se te quiebre en las manos,

no te perdere;

aunque borres el último camino que te queda,

no te perderé;

aunque adquieras la forma de la ausencia absoluta,

no te perderé.

Si te vas un día

y en la distancia no te alcanzo a ver,

bajaré, en sueño, al corazón los ojos

y alli, junto a mi pena, alli te encontraré.

(LL.....p.131). 
En las transformaciones señaladas en la naturaleza del objeto poético, y cuya transición se cumple a partir de una categoría espacial (del exterior al interior) tenemos una más radical hacia el final de su producción: la aniquilación del objeto en cuanto artificio, en cuanto está sostenido en la palabra, que es ejecución de un código. La palabra tiene una función completamente anexa, circunstancial: canta las cualidades del silencio. Esta propuesta bastante difundida en la estética contemporánea, por un lado, reconoce explícitamente la insuficiencia del lenguaje como instrumento capaz de recrear absolutamente la experiencia vivencial que intenta expresar el creador; y por otro, otorga al lector la máxima libertad en la instancia de reconstruir el mensaje: en el diálogo entre el autor y lector, la palabra es apenas un indicador de corrientes más profundas del pensamiento. La reconstrucción se logra (subjetivamente) a partir de los indicios mínimamente sugeridos, y que no requieren necesariamente la tradicional búsqueda de lo "acabado", la forma definitiva del poema. El objeto de arte es un signo transitivo, algo que indica una dirección hacia algo que está fuera de él.

Ya en Como el aire y el día podemos apreciar su conciencia de esta dimensión, aunque no referida específicamente a la actividad estética:

Tantos verbos y adjetivos

para qué, si lo mejor

en los diálogos de amor

son los puntos suspensivos...

(PyC,p.84)

que está desarrollada plenamente en Umbral del silencio

\section{Coplero}

Hallo su voz

verdadera

casi a orillas

del silencio:

de tanto abreviar el canto

acabó

siendo coplero

en que la reducción del lenguaje aparece como una instancia transitoria, y que posteriormente hará lugar a un nuevo código.

El poeta se reconoce en el límite entre el objeto y su nombre; se encuentra condicionado por el eje espacio-temporal de la luz y por el sonido "que puede prescindir del espacio" (Borges).

\section{Límite}

(..)

Ahora

solamente me queda esta penumbra. 
(..)

Ahora

solamente me queda este silencio.

(...)

(U.S.,p.17).

Frente a la ausencia de la palabra, de la voz, lo cual constituye una manifestación pasiva, hay una valoración de la acción. En términos de la teoria de los actos de habla, una supremacia del acto ilocutivo sobre el acto locutivo. comunicante:

El lenguaje pierde su valor en sí mismo, para reducirse a una mera función

\section{Tarea}

Qué tarea tan obscura

la de borrar horizontes:

es como sembrar neblina

en la mirada del hombre.

$Y$ qué tarea tan pura

la de pintar horizontes:

es como sembrar el sol

en el ojo de la noche.

(U.S.,p.55).

en que el arte se proyecta en la vida, asume un papel activo, se constituye en una propuesta efectiva de transformación humana, presente en "Por Ti":

Señor, por Ti

mi corazón como una achira roja

calladamente sangra.

(LOM, 52)

\section{LA PALABRA EN EL TIEMPO}

De las dos dimensiones determinantes de la realidad -espacio y tiempoambas son consustanciales con el ser del hombre. El tiempo es único (según la experiencia diaria, al margen de las explicaciones científicas) e inevitable.

"Del tiempo medido por la intuición y razonado por la conciencia, nace para el hombre su condición de ente histórico" señala Segundo Serrano Poncelaxiv.

Esta condición de "ser histórico" del hombre lo conduce desde la contemplación hacia la meditación; poco interesa si el objeto utilizado es exterior 0 interior, pues necesariamente la cuestión mantendrá su naturaleza: interrogante que 
busca la proyección del presente, que se preocupa, esencialmente, por el sentido del ser.

Un hecho o un objeto adquiere su significación plena cuando está inserto en un contexto. El hombre frente al tiempo procura límites, reclama sistemas ideológicos que lo expliquen (aquí se ubican las posiciones racionalistas y las materialistas. Un poeta como Meloni difícilmente recurra a la primera. La fe en la cual palpita la intuición, orientará su espíritu al idealismo). La religión cristiana le proporciona una concepción fundante del sentido de la vida, en cuanto constituye una vía ascendente hacia lo Supremo.

El devenir se constituye en la "experiencia" acumulada en la historia personal: fuente de reflexión y de interpretación del mundo.

El poeta puede, si lo desea, penetrar en la sustancia de la temporalidad como materia poética, materia que lo conducirá ineludiblemente a la reflexión "En sus cumbres, la gran poesía es pensante y el gran pensar es poético".xV

Antonio Machado recalcó frecuentemente la temporalidad del arte, con una frase citada a menudo: "poesía es palabra en el tiempo". Precisamente en un ensayo sobre su vida y su obra, leemos: "Sus vivencias tratan de objetivarse por medio de la palabra y he aqui al poeta efectuando esa mágica operación que consiste en revelar su temporalidad como via para alcanzar la esencia del ser. Ha partido de su propia existencia, convertida en temple de ánimo; la ha punzado con la palabra más auténtica y original que brota de su vida, no de su intelecto (...) y ha dado lugar al poema." $x v i$

Aunque el concepto de "tiempo" en la poética de Meloni no sea radical, de todos modos constituye un tema subyacente a su pensamiento y que muchas veces ilumina sus intuición.

Tampoco adherimos a una consideración simplemente vitalista del tema; con cierta coherencia, el llamado "temple de ánimo" generador de la emoción, aporta elementos de carácter estético.

Lo temporal se expresa de diferentes maneras desde una perspectiva diacrónica de su obra, al punto que se pueden detectar cuatro períodos definidos tentativamente:

1. Composiciones anteriores a 1965 (que en su obra aparecen reunidas en su primer libro: Tierra ceñida a mi costado,) y que pueden denominarse genéricamente como "Intemporalidad".

Es común afirmar que la poesía es intemporal. Se alude aquí no a su sustancia sino a la posibilidad de mantenerse vigente para el lector de diversas épocas, en cuanto desdeña lo circunstancial (o biográfico) y atiende a lo esencial, lo perdurable del hombre y del mundo.

No se usa aquí tal acepción del vocablo; nos referimos estrictamente al valor semántico de los poemas. Para expresar con palabras de Antonio Machado, la denominaríamos "esencial".

Pero la esencialidad, concebida por él como una actividad destemporalizadora producida por el pensamiento lógico, se da en nuestro poeta por un acceso diferente, a través del carácter eminentemente descriptivo de su lírica. 
El devenir es aludido sólo tangencialmente: el objeto poético configura un intento de abstracción de la esencia del paisaje en un presente detenido:

\section{Mediodía}

Mediodia de sol. La tierra vibra

entre la luz y el canto febril de las chicharras.

Un tropel de jinetes al galope

finge el perfil del horizonte en llamas.

Bajo los algarrobos solitarios

los rebaños dormitan con las cabezas gachas.

Lejos, una perdiz talla su angustia,

con silbos de humildad. Es la obsesión del agua.

Ni una nube slquiera. Ni una nube

el vidrio hostil del firmamento empaña.

$Y$ el viento norte, con su crin de fuego los banderines del maizal abrasa.

Hay escasas y breves excepciones en los poemas: "Agua de lluvia", "Primavera" y "Lucero". Pero queremos señalar especialmente dos composiciones: "Colonia de San Antonio" y "Chaco". En el primero se insinúa un recurso clave de su poética posterior: el desdoblamiento presente-pasado; en "Chaco" se incorpora la dialéctica entre el recuerdo y el olvido:

\section{Colonia de san Antonio}

\section{(...)}

Porque ahora la nombro con emoción de ausencia, toda su geografía se me antoja añoranza.

Sobre el mapa del pecho los caminos dibujan un solo rumbo: el suyo. $Y$ una sola distancia.

$Y$ vuelven las jornadas de sol y viento norte a encenderme la sangre y a golpearme la cara.

(PyC,p.25) 


\section{Chaco}

\section{(...)}

Cuando muera a la sed de cada día, al sol, al aire, a la raiz, al pajaro, escóndeme en tu médula piadosa, junto a la flor abierta de tu llanto,

y devuélveme en cálido recuerdo los días que dejé, como sembrándolos, en los caminos de tu piel ardida, tierra ceñida a mi costado, Chaco.

$$
\text { (PyC, p.32). }
$$

La poesía está en el paisaje, a la manera de una imagen total, captada en un presente vasto. El objeto estático, tangible, apresado en el instante.

Tales manifestaciones señalan una particular relación del hombre con el mundo a través de los sentidos, los cuales proporcionan los datos del espectáculo interior. Esta apertura es consecuencia de una voluntad de traducir el mundo en cuanto tiene de novedoso para la sensibilidad.

El papel de la subjetividad aparentemente es minimo: las alusiones, referencias, asociaciones son escasas; el eje de la sensibilidad ordena los datos, según un proceso intelectual, superando la instancia perceptiva. Hay necesariamente un distanciamiento entre el sujeto y el objeto, pero sólo el indispensable para nominar la experiencia, no lo suficientemente amplio como para enriquecerla con sentidos subjetivos.

2. Producción comprendida entre 1965 y 1980, que incluye el cuerpo principal de su obra: "La palabra en el tiempo".

Como el aire y el día inaugura una visión que se mantendrá y explicitará en la subsiguiente producción hasta La palabra desnuda.

La estética de Meloni, fundada en una total comunidad entre la vivencia y la palabra, se mantiene uniforme, pero la sustancia de la imagen poética se modifica hasta ser el equivalente de la pura emotividad. Hay un cambio objetivo que es una causa inmediata: el referente se ha desplazado hasta instalarse en la interioridad del poeta. Pese a ello, alude todavia, en un segundo grado, al exterior, cuya existencia determinante animó su primer libro. El modo más simple (y natural) que escoge es la evocación:

\section{Las gaviotas}

Mientras las nubes pasan a ras de las catalpas y baja sobre el campo una fina llovizna,

no sé por qué yo pienso en las gaviotas que, alocadas, detrás de los arados iban. 


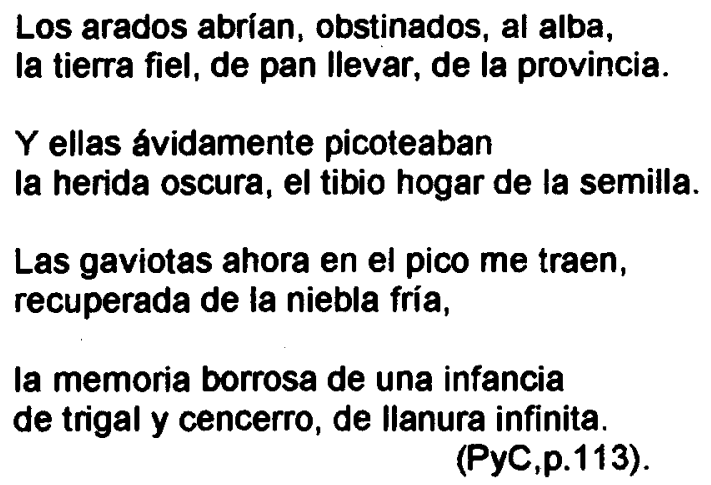

He aqui una primera manifestación de la conciencia del tiempo que lo lleva a rescatar la experiencia a través del recuerdo:

Tu memoria es como el agua:

nunca se pierde;

como el agua que va al mar

y la nube la devuelve.

(PyC,p.92)

Esta insistente "vuelta hacia atrás" manifiesta implícitamente un patrón valorativo de la realidad que adquiere las dimensiones míticas: el Tiempo del origen, la edad dorada, que se actualiza y vive en el poeta y lo acerca a la experiencia de los superior, purificado.

\section{En lo puro del día}

Te recuerdo, colonia, en lo puro del día:

en el alba, el arado, y el silbo del boyero;

en la lluvia que pinta los sembrados de verde, y restalla de gozo en la piel del camino;

o en los atardeceres cuando vuelve el silencio y se recuesta sobre tu fatiga.

Te recuerdo en la mano tendida de tu gente, abierta a la amistad como una melga nueva;

o en las volantas rusas

que pasan rumbo al pueblo lentamente, con una carga de algodón y otra de sueños. 


\begin{abstract}
Y también en la voz familiar de la escuela, que sale a recorrer cada mañana las chacras y los montes;

y en el deslumbramiento de tus niños cuando Dios se entretiene dulcemente sembrando de imprevistas respuestas su inocencia.
\end{abstract}

Te recuerdo, colonia, en lo puro del dia; lo demás se lo dejo al diente del olvido.

$$
\text { (LL...,P.109-110) }
$$

El espacio paradigmático de Colonia de San Antonio continúa fluyendo en la inmediatez de la percepción, subyace en la experiencia cotidiana, abreva la sed de amor, humildad, laboriosidad; valores éstos que sustentan sus más preciados fines éticos, en concordancia con su vocación humanística.

Estos indicios que aparecen nos llevan a consignar una referencia a un tema muchas veces relacionado por la crítica con la poesía: el mito. Un aspecto esencial del mito reside en que su conocimiento remite necesariamente al origen (en tal sentido, es una cosmogonía) y tiene por función "relevar los modelos ejemplares de todos los ritos y actividades humanas significativas: tanto la alimentación o el matrimonio como el trabajo, la educación, el arte o la sabiduria. "xvii Como aproximación al tema, sería provechoso rastrear y dimensionar hasta qué grado se puede hablar de mito de la Tierra, a través de la presencia de la naturaleza (representada por la Colonia de San Antonio), en esta poética.

Mircea Eliade afirma que el mito (historia sagrada y verdadera protagonizada por seres sobrenaturales) relata el origen primordial de todo to existente (lo explica por el origen). Se puede establecer cierto paralelismo (de manera parcial y sin afán de conservar la estricta naturaleza del mismo) entre el concepto de Historia universal (cosmogonía) y el de historia personal; y nos encontraremos con que el pasado individual está constituido también por una serie de hechos que han significado un comienzo, a través de los cuales el hombre se ha sentido unido con los "comienzos" míticos:

\title{
Instante
}

Mi corazón por un instante es simple, suave y espiritual como una flama de oro que arde entre las rosas de un altar al alba.

Mi corazón por un instante es claro como esta luna cálida que asoma ahora su frente niña sobre las catalpas. 
Mi corazón por un instante es limpio como una espada,

o más; como la reja de un labriego pulida en el trabajo y en la fragua.

En ese instante azul, isla viajera, un ángel me convoca; cuando pasa vuelvo a la patria original del hombre, a la raíz del viento y de la llama.

(PyC,p.39)

Otra forma de expresar su internalización del tiempo para superar el devenir es a través del arte. Sin ningún tipo de pretensión, cita a la copla en particular, que es capaz de perdurar en la memoria popular. Para ello, ha de cumplir con el requisito de expresar fundamentalmente la experiencia del hombre, la que adopta genéricamente la denominación de "pena", en la que sintetiza una visión del dolor, del sufrimiento:

\title{
De todo lo que he vivido en esta larga jomada sólo cuenta lo sufrido. Lo demás es casi nada.
}

(PyC,p.62)

El hombre, como ente temporal, adopta el canto (la copla) para traducir su visión del devenir: "Inquietud, angustia, temores, resignación, esperanza, impaciencia que el poeta canta, son signos del tiempo, y a la par, revelaciones del ser en la conciencia humana" (Antonio Machado).

\author{
Solo con mi pena un día \\ a orillas del río estaba: \\ el agua, que es tiempo, huia; \\ la pena, fiel, se quedaba.
}

(PyC,p.61).

En una primera metáfora, la pena se identifica con la copla ("Zumo de un mismo racimo/ sangre de una misma arterial la pena fluye por dentro/ la copla fluye hacia afuera" -PyC,p.86) y de esta última se busca lo duradero, trascendente. Su pena en cuanto motivación compartida con sus semejantes, es algo temporal en su esencia, porque es propia del hombre en su devenir y al mismo tiempo adquiere la categoría de lo esencial, porque sus motivos desconocen lo circunstancial. 


\section{Suerte}

Qué suerte la del coplero si anclada, como una boya, en el río que lo lleva

queda la luz de su copla.

$$
\text { (LL...,p.142). }
$$

Esta composición de La palabra desnuda, reitera la idea ya vertida en "Coplero" de Coplas de Barro:

$$
\begin{aligned}
& \text { Cuando un coplero se muere } \\
& \text { empieza a andar su memoria; } \\
& \text { lo que la muerte le quita } \\
& \text { se lo devuelve la copla. }
\end{aligned}
$$

(PyC, p.68)

La reflexión acerca del tiempo manifiesta obviamente la relación del hombre con las cosas:

\section{Despedida}

Muchas cosas se fueron quedando en el camino.

Uno ahora las ve como entre niebla, lejos,

agitando el pañuelo del adiós en el aire.

Ellas sufren, es claro, nuestro mismo desvelo.

Ayer, a nuestro lado; hoy no pueden seguirnos porque vamos de prisa con un paso de invierno. Y nos miran con lágrimas: saben que nuestro viaje ya se acerca a su fin y no tiene regreso.

(PyC.p.134).

El universo se anima en una personificación total. Pero la diferencia entre lo humano y lo inanimado reside en el vínculo temporal, que ata al hombre, mientras las cosas permanecen al margen (recordamos aqui el memorable poema "Las cosas" de Jorge Luis Borges).

Es importante rescatar la primacia del animismo que se extiende sobre la imagen, conservando la premisa de su maestro Machado, cuando reprochaba a los poetas jóvenes de su época "el empleo de las imágenes más en función conceptual que emotiva."

Pero el hombre (ser en el tiempo) es parte inevitable de su mundo; su interioridad contiene también un espacio (aunque espiritual) configurado por manifestaciones apenas perceptibles. En consecuencia, las transformaciones del exterior son también interiores: 


\begin{abstract}
Las penas a veces llegan y se van como han venido, pero el corazón del hombre ya no vuelve a ser el mismo.
\end{abstract}

(PyC,p.16).

\title{
Cuando esta rosa muera.
}

Cuando esta rosa muera

también ha de morir algo del alma mía:

tal vez un sueño antiguo, una dulce quimera...

Caerá deshojada toda la hechiceria de lo puro y lo bello, cuando esta rosa muera entre los últimos relámpagos del día.

$Y$ nunca más podré leer en el idioma de su color, de su tersura y de su aroma tanta maravillosa poesía,

ni ser como antes era...

Cuando esta rosa muera también ha de morir algo del alma mía..

$$
\text { (LL...,pp.122-123). }
$$

El tiempo es, naturalmente, el receptáculo donde se insertan estas transformaciones que objetiva en un detenido ensimismamiento. El poeta en el tiempo, alerta su conciencia acerca del transcurso, no expresa angustia ni desesperación, sino el tomo meditativo que refleja la aceptación del destino con una resignación casi mística.

\section{Para que nos duela menos pensar que la vida acaba, habrá que mirarla sólo como una cosa prestada.}

$$
\text { (PyC,p.91) }
$$

3. Producción de la década de 1980: (Umbral del silencio, 1983; La luz que uno amaba, 1987; Antes que sea noche, 1990): cambio de actitud vital.

Anteriormente aludimos al "movimiento hacia atrás" articulado por la memoria, como el eje de su poética que abarca hasta La palabra desnuda. Desde Umbral del silencio la actitud vital es diferente: frente a la inserción del presente como en un sostén donde se apoyan las imágenes del pasado, ahora conocemos una poesía cuya sustancia temporal se convierte en una búsqueda centrada en el futuro, en la cual la palabra adquiere trascendencia por su estatus perlocutivo antes que constatativo. 
Muralla.

Quien levanta una muralla trabaja para la muerte:

la vida sólo se anima

si tiene un camino enfrente.

Si tiene un camino enfrente.

Quien derriba una muralla trabaja para la vida:

cuando el corazón galopa

la muerte se desanima.

La muerte se desanima.

(U.S.,p.9).

Mediante esta simples oposiciones, el poeta expresa un mundo esencialmente considerado desde una perspectiva de valoración original; una realidad que es un escalón para el futuro, que tiene en sí misma hambre de futuro.

La dialéctica del pasado-presente integrada a un esquema de búsqueda incesante, que tenia un mediador imprescindible en la memoria, ahora modifica sus términos y prescinde de éste (al menos en el sujeto) porque la temporalidad introduce la necesaria proyección.

Tarea.

Qué tarea tan oscura

la de borrar horizontes:

es como sembrar neblina

en la mirada del hombre.

$Y$ qué tarea tan pura

la de pintar horizontes:

es como sembrar el sol

en el ojo de la noche.

(U.S.,p.55)

Lentamente.

Lentamente

vamos,

como sin ganas de andar;

como alargando el camino 
para que dure un poco más;

para que no acabe hoy

lo que un dia

acabará.

Lentamente vamos,

como si andando despacio

no fuéramos a llegar.

(LL...,p. 186)

Esta concepción dinámica del objeto poético se opone a las dos formas anteriores de anclar en el presente: lo descriptivo y lo evocativo.

En la cumbre de su experiencia (vital y poética) Meloni necesita afirmar su esencia temporal en la realidad, descubre (mejor, toma conciencia de) que "derribar una muralla" o "pintar un horizonte" es una tarea que supera lo estético, y en ella se trasuntan los valores clave de la vida defendidos por él.

\section{Búsqueda.}

En la búsqueda de Dios se nos va toda la vida, mientras El, a nuestro lado, tal vez juega a la escondida.

(U.S.,p.30)

Lo divino, inescrutable aunque presentido, tal vez lo espera, pero indudablemente lo acompaña ("A veces/ siento su mano/ cálidamente abandonada sobre mi hombro"- U.S.,p.19).

La misma presencia del Creador (constante en su obra) ahora se circunscribe también a aquellas circunstancias en que el poeta asume su devenir como un inevitable sometimiento al futuro. Lo único seguro, la presencia implacable detrás de la puerta que abrirá, es, necesariamente Dios. La vida (el ser del hombre en el tiempo) encuentra en El su fundamento y por ello elude las inseguridades, el temor, y se abandona a la confianza.

\section{Ella nos basta.}

Están de más la flor, la piedra y la palabra: sobre nosotros

la muerte luce espléndida.

Ahora

ella nos basta.

Ella es la flor que nunca se marchita, 
la piedra que la lluvia no desdora,

la palabra que nadie contradice.

Reitero: ahora

ella nos basta.

(AN, p.51)

4. Producción posterior a 1990: donde se ubican La otra mirada (1992) Memoria y olvido (1993), Leve Fulgor (1995) y Todo se vuelve azul (1997): Intemporalidad.

Este último período en la producción de Meloni presenta de manera singular el cosmos poético abordado en su obra precedente. ¿Nueva perspectiva o nueva visión?, ¿Otra manera de relacionarse el yo con el mundo? ¿Consecuencia de la experiencia vital o de la experiencia literaria?

Los temas persisten, maduran algunos, otros pierden terreno, pero no representan un rasgo destacable como manifestación de un cambio de sensibilidad. Temporalmente se advierte un cierre, un "retorno" al principio, en cuanto a la búsqueda de trascendencia que se concreta ahondando en la materia poética lo esencial del mundo.

La diferencia radica en que este desasirse de lo circunstancial se opera a través del salto metafísico: el mundo aparece reducido, simplificado; su existencia se reduce a la esencia y la palabra cava un espacio acotado que la orientan casi al silencio.

La evocación se afirma, aquella calidez de la palabra impregnada de subjetividadxviii toma forma sin embargo en nombres y lugares.

Paralelamente, la meditación ocupa un lugar de privilegio, se constituye en el parámetro de su palabra. La actitud reflexiva, que se sustenta en la introspección como un método para hallar aquellos contenidos que trascienden la experiencia individual, es uno de los caracteres propios del espíritu clásico.

El objeto que logra el equilibrio ante la insistencia de la conciencia para convertir la obra en un logos personal que tiene por objeto las ambiguas migraciones de la nostalgia, los gránulos sin color (aunque con peso multiplicado) de la memoria. Evita sin embargo lo que podría desembocar en una especie de solipsismo.

Tampoco hay contradicción entre ambas actitudes, "el texto instituye en el seno de la relación humana -corriente- una especie de islote, manifiesta la naturaleza asocial del placer"xix ni siquiera una separación perceptible. Las categorias de lo estético trascienden las formas de ordenamiento que imponemos a la realidad; ignoran los principios lógicos (la contradicción, el tercero excluido, la analogía). El objeto simplemente está ahí como algo dado y que debe ser juzgado sólo a partir de esa condición.

\section{Sombra}

El árbol de la memoria mala sombra a veces da, que a veces lo que uno busca 
es olvidar, olvidar

(U.S.,p.22)

La actitud central de la poética de Meloni ha consistido, como ya lo señalamos, en un permanente abrevarse en el pasado. La materia poética ha sufrido el proceso que impone la memoria para lograr quedar en libertad. En un lento proceso de sedimentación inconsciente, se produce la eliminación gradual de los resquicios de asociaciones que entorpecen la captación clara del objeto a través de la palabra (la depuración formal y conceptual). Los poemas continúan siendo pequeñas órbitas cerradas unitarias. La imaginación describe su trayectoria, recupera lo esencial y cierra el círculo sin atraer satélites ni aquel tipo de materia que Barthes señala como esencial en la literatura contemporánea: la digresiónxx.

Memoria es purificación. Memoria es la fragua de la Poesia. Regresamos a la copla citada; en ella se produce un fenómeno curioso: la doble asociación negativa (desde el punto de vista religioso y tradicional -o diríamos mitológico-) que se expresa en el poema.

Por un lado, la memoria aparece metaforizada a través de un árbol. Es inmediata la connotación que adquiere con referencia al Génesis. Inmediatamente, la metáfora le sirve de nuevo para nombrar el recuerdo con un término bivalente: sombra. La pertinencia a un contexto de discurso expresivo multiplica sus significados, produce un hervor en la cáscara de las letras (o mejor, los sonidos) y las burbujas desfiguran su "significado" usual. "La palabra no tiene significado preciso. Es un camaleón que nos muestra matices, y aún colores distintos" afirma un formalista rusoxxi.

Y acá, recordando la noción de "campo asociativo" (relaciones asociativas, según F. de Saussure)xxii podemos establecer dos campos semánticos:

A: Sombra, oscuridad, tiniebla, opacidad, lo negro, sobrecogimiento, temor, neurosisxxiii.

B: Sombra, protección, intimidad, frescura, solaz, reposo, hedonismo, placerxxiv.

Admitiendo la posible arbitrariedad de los campos formados, pero seguros de la consistencia intrínseca de estas series, podemos concluir que la ambivalencia aparente del vocablo "sombra" desaparece en el fondo, y se convierte en el núcleo primigenio de la escritura. Encontramos, incluso, un primer significado del término, obtenido intratextualmente: "sombra"="lo que perdura". "...mala sombra a veces da; lque a veces lo que uno busca/ es olvidar, olvidar".

Es precisamente esta última acepción la que podemos relacionar con el último verso a través de una antítesis: sombra/olvido $=10$ que perdura/lo que desaparece=construcción/desconstrucción. Lo que el poeta hace es asumir una forma de construir el objeto poético a través del único camino legítimo: la memoria.

Por último, observamos la reiteración "a veces". Más allá de los motivos (tal vez fortuitos) que determinaron su presencia, su funcionalidad en el poema es neutra, ya que indica que a $X$ elementos de $B$ corresponde $A$ (que lo que se quiere olvidar, es conservado). La actitud, en consecuencia, se mantiene; la relación con el mundo (poético) está, en general, implícita en el anterior. 
Al comienzo se ha mencionado la experiencia como sustento de esta actitud poética. Vocablo ambiguo, del que rescatamos los usos en "la experiencia religiosa", "la experiencia poética", "la experiencia del amor", que significan, en síntesis, un cambio de naturaleza que permite la manifestación de la raiz misma del hombre: un estado de unidad primordial. "En el encuentro amoroso, en la imagen poética y en la teofanía se conjugan sed y satisfacción: somos simultáneamente fruto $y$ boca, en unidad indivisible." dice Octavio Paz. El hombre -agrega- "es temporalidad que quiere aquietarse, contemplarse a sí misma. El hombre se imagina y al imaginarse se revela"xxv.

Esta experiencia, que según este autor tiene por finalidad la revelación de nuestra condición original, está contenida en lo que denomina el "salto al vacío", experiencia de "lo Otro" y se manifiesta en el sujeto en la forma de una radical extrañeza ante el mundo cotidiano, del cual apropia lo perdurable en el verso. "Lo feliz de la imagen reside en que es un límite para lo indefinido. Arco endeble, que nos mantiene tanto a distancia de las cosas, como nos preserva de la presión ciega de esta distancia"xxvi.

\section{De rodillas \\ Mírame, otoño; \\ mirame de rodillas: \\ hombre vencido,}

llágrima secreta.

Me recorro por dentro

y me descubro tal cual soy:

Atierra de nadie.

Mirame, otoño;

mirame de rodillas:

botella echada al mar

Icon un mensaje sin destino.

Sí, lágrima secreta,

/idioma indescifrable.

(T.A.,p.49).

El ser que se enfrenta a lo inefable. El precisamente éste el sitio clave donde conviven los contrarios, donde la unidad esencial de las cualidades es percibida no como transición sino como una cualidad "naturante" (en el sentido dado por Spinoza) del mundo.

El hombre: lugar de encuentro de los contrarios, punto de síntesis donde convergen la vida y la muerte. Estructuralmente, ésta es una dimensión en que podemos aplicar el concepto de otredad señalado por Octavio Paz: "la experiencia de la otredad abarca las dos notas extremas de un ritmo de separación y reunión, presente en todas las manifestaciones del ser (...) La poesía no se propone consolar al hombre de la muerte sino hacerle vislumbrar que vida $y$ 
muerte son inseparables: son la totalidad. Recuperar la vida concreta significa reunir la pareja vida-muerte, reconquistar lo uno en lo otro, el tú en el yo, y así descubrir la figura del mundo en la dispersión de sus fragmentos. "xxvii

La cultura occidental ha configurado un aura de prestigio en torno de la palabra. A ello han contribuido la religión, la filosofía, las mitologias, las tradiciones y los hábitos de los pueblos, reforzados por las estructuras económicas defensoras de la burguesía. Tampoco el marxismo o el existencialismo han relativizado su valor.

Por otra parte, se ha fundado una cosmovisión a partir de la unidad entre el hombre y Dios; entre el hombre y el mundo. Frente a esto, la palabra retrocede, y su importancia se reduce y la experiencia trascendente se refugia en el silencio:

\section{Reintegro}

Ya he dicho, vida, la palabra que era mia; ya he bebido tu sol hasta el derroche; te devuelvo la luz, toda la luz y el dia: me quedo con la sombra y con la noche.

(LOM,p.20)

De esta manera, el ser del poeta reconoce su lugar en el mundo, que es el lugar en el lenguaje. La nominación como acto ha pasado a constituir parte del texto. El silencio no es una actitud pasiva; es una apropiación activa del sentido del mundo y de las cosas, un despojamiento hacia lo perdurable: "Cuando el poeta se siente desprendido del mundo y todo, hasta el lenguaje mismo se le fuga y deshace, él mismo se fuga y aniquila. $Y$ en el segundo momento, cuando decide hacerle frente al silencio o al caos ruidoso y ensordecedor, y tartamudea y trata de inventar un lenguaje, él mismo es quien se inventa y da el salto mortal y renace y es otro"xxviii

La experiencia de la creación (la actitud ante el alumbramiento intuitivo) consta de estos dos aspectos, el primero de los cuales consiste en el despojamiento radical de las preconcepciones que racionalizan la experiencia; el segundo, de reconstrucción, hace posible la aparición del signo. Creemos hallar una diferencia de naturaleza en ambos: el primero es externo, involuntario; se le impone al poeta. El segundo es interno, voluntario, lleva en sí una aspiración a la procreación. En él está implicita una búsqueda del sentido para el objeto que se construye (la palabra poética). En ese instante, el signo está en el contexto y viceversa.

En este punto, la sensibilidad de la creación hace presente la Vida (con todas sus implicancias: lo social, la historia, la filosofía) como una explosión: ella es a la vez fuerza expansiva y configuración. El poeta, entonces, busca refugio en lo trascendente:

\section{Plegaria}

Señor, estamos tristes: tristes de haber nacido; de ser hombres;

por haber recibido como herencia /una culpa enigmática; 
y todo to que luego
se nos fue dando por añadidura:

(lejos de Ti) nuestras preguntas sin respuesta;

(lejos de Ti) nuestro desasosiego;

(lejos de Ti) nuestra desesperanza.

Señor, compréndenos;

no mires nuestras lágrimas rebeldes, de impotencia, con tu ira bíblica:

lla de un rayo dispuesto en cada mano.

Señor, compréndenos;

Tú sabes que tenemos fundamentos de sobra para estar tristes.

$$
\text { (Tristes, lejos de Ti). }
$$

$$
\text { (T.A., P.41) }
$$

Hay, sin embargo, una voluntad de recurrir a un nuevo código para mantener la comunicación con el Ser y con el mundo, una búsqueda de la inteligibilidad en el acto mismo de la poetización: el hombre se ha encontrado consigo mismo, ha logrado identificarse con lo ajeno, lo Otro. La experiencia poética es capaz de conformar en el hombre un nuevo ser de lenguaje.

El poeta trasciende el entorno y su palabra instaura el ser de las cosas en una aprehensión que tiene una vehemente aspiración de eternidad:

\author{
Visión \\ Desnuda como un relámpago \\ te vi, poesía pura; \\ pero sólo por el ojo \\ de la cerradura. \\ Te vi como te soñaba: \\ en tu espléndida hermosura; \\ pero sólo por el ojo \\ de la cerradura.
}

(LOM,p.21)

\title{
EL ESPIRITU CLÁSICO
}

Paul Hazardxxix, en un esclarecido estudio en el que indaga sobre la génesis y la inserción cronológica de la "ruptura" del pensamiento moderno con respecto al medieval, caracteriza la mentalidad del hombre clásico: "Hay periodos líricos: cuando se los estudia, es grato escuchar sus armonias, aspirar sus efluvios sonoros, dejarse llevar por sus músicas sutiles hasta 10 inefable; toda tierra no 
es más que un canto". La obra total de Meloni se refiere, como lo señalamos, a su residencia en la Colonia de San Antonio, y manifiesta una compenetración profunda con el entomo "en mi obra. Muy breve, por cierto, he querido recrear el paisaje rural del oeste chaqueño, duro, áspero y dificil; algodonero y maderero donde pasé casi veinte años como maestro rurar' $\mathrm{xxx}$

Pero el medio efectivo de concretar este diálogo entre el espíritu y el mundo en un proceso de identificación consiste en la revelación de un código que esté al margen de lo transitorio: un lenguaje en el nivel mítico de su acepción, del que no estén ausentes los valores.

La poesía de Meloni constituye la manifestación de aquel canto a la tierra de "Las tuscas". Al margen de estos signos de una actitud vital que nuevamente nos remite a la norma del equilibrio, de la amistad y la mesura propugnadas por Montaigne, la idea que comentamos considera una consecuencia inmediata: el conocerse a sí mismo. La proyección universal en los planteos de su obra, sin dudas, alude a una profunda reflexión del hombre sobre sí.

La premisa de la estabilidad también se extiende, ya en un ámbito estrictamente literario, como: *la visión de un mundo del cual se rescata un rasgo primordial: lo esencial, que se traduce mediante símbolos constantes. A través de las reiteraciones circulares, se confiere peso a la sustancia de la obra; *una estética defensora de lo estable, en el plano del lenguaje, se opone naturalmente a las distintas formas de aventura, productos de las innovaciones estilísticas o lingüisticas; *las coplas se constituyen en la manera eficaz de expresar la idea justa, mesurada, y tienden a transmitirse en la memoria colectiva. Evidentemente, Meloni respeta fielmente las estructuras clásicas, tanto en el aspecto formal como en el contenido.

Su lirismo proviene, por una parte, de su actitud vital, en que la docencia ha dejado sus huellas profundas. También se da en la transmutación del ambiente hostil que lo rodeó durante dos decenios y que constituye el eje de su creación poética. ¿No es visible una arraigada aspiración a la belleza que ha pretendido lograr no sólo para sí, sino para los demás? "Escribo por necesidad de transmitir mis sentimientos; por una intención, desde muy joven, de crear belleza por medio de la palabra. "xxxi

Paul Hazard continúa su caracterización: "Permanecer, evitar todo cambio que amenazará destruir un equilibrio milagroso: éste es el deseo de la edad clásica. Son peligrosas las curiosidades que solicitan a un alma inquieta; peligrosas y locas, puesto que el viajero que corre hasta el fin del mundo no encuentra más que lo que lleva: su condición humana. (...) Que la encuentre, al contrario, para aplicarla a sus problemas eternos, que no se resuelven disipándose. (...) El espíritu clásico, en su fuerza, gusta de la estabilidad: quisiera ser la estabilidad misma"xxxii

Literalmente, Meloni ha preferido la estabilidad al movimiento. Sus veinte años de permanencia en la Colonia, con breves estadías en lugares cercanos durante las vacaciones, muestran su predisposición a permanecer en un sitio, resignando las posibilidades de los cambios proporcionados por los viajes. Luego, su asentamiento en Resistencia, desde 1956 hasta la fecha corrobora lo afirmado: el hombre, se acerca en este aspecto al ideal clásico. Procura encontrar la felicidad en un mundo seguro, ordenado, estable, capaz de ofrecerle la tranquilidad y transmitirle la armonía 
necesaria para vivir plenamente su existencia en compañia de su familia y en la frecuentación de sus amigos.

Esta permanencia le posibilita el conocimiento de las cosas que lo rodean. A medida que las conoce, madura un sentimiento perdurable que supera los límites de la percepción intelectual. El poeta demuestra una profunda compenetración con el mundo de objetos próximos, y desde alli se proyectan las manifestaciones de una actitud de aceptación de la realidad y de sí mismo, con innegable lucidez:

\section{Pueblo.}

Cuatro calles polvorientas

y un puñadito de casas.

Bajo la cúpula verde

de algarrobos y catalpas.

Una iglesia, casi en ruinas, santificando la plaza.

En la plaza, algunas tipas, y en las tipas, las cigarras echando a rodar los rios estivales de sus flautas...

Para la dicha es muy poco, y con ser tan poco, basta.

$$
\text { (LL...,p. 12) }
$$

\section{Colonia de San Antonio.}

(...)

Por la fe de su gente, la de ayer y de ahora, en la tierra que sufre la nostalgia del agua;

por el surco que tiene la dimensión del hombre, por el hombre que tiene la dimensión del alba.

Por su nombre anudado a mi voz para siempre, yo le digo: Colonia de San Antonio, gracias.

(PyC,p.25)

El mismo Hazard señala como paradigma del hombre clásico al Caballero del Verde Gabán, con quien se encuentra el Caballero de la Triste Figura en el Capitulo XVI de la Segunda Parte de El Quijote. Tiene hacienda sin exceso, diversiones, lecturas, sin lujos ni escasez. Le gusta una libertad razonable, la justicia, la concordia; da a los pobres, teniendo cuidado de no ceder a la vanidad; procura poner en paz a los que están. desavenidos; es devoto de la Virgen, y lleno de confianza en la 
misericordia de Dios. "Don Diego Miranda (tal el nombre del Caballero) prefigura el ideal de la sabiduría clásica: sabe que la existencia no puede dar nada más dichoso que una armonía del espíritu, de los sentidos y del corazón"xxxiii

\title{
Ahora.
}

Ahora esta mirada, tan limpia, de la luna sobre tu corazón y el mío detenida mientras vamos creando, de la mano, un mundo luminoso de pan y de semilla.

Sobre el sembrado cálido los árboles dibujan imágenes de vidrio, pero no nos lastiman. Ni nos duele el silencio de la noche porque llevamos en la sangre el día.

Hay un profundo olvido del tiempo y su piqueta; después vendrá el otoño con sabor a ceniza. Ahora esta mirada, tan limpia de la luna sobre tu corazón y el mío detenida.

(PyC,p.36).

Henri Peyrexxxiv analiza también los rasgos de este período: no considera totalmente pertinente el calificativo de "racionalista" asignando habitualmente, pese a las conocidas asociaciones en tal sentido (The Age of Reason); propone, en cambio, como más apropiado el calificativo "intelectualidad". Se alude aquí a una presencia constante del yo intelectual del creador en su obra: "La era clásica se anuncia como una luminosa e insolente conciencia de si mismo". El hombre pretende encontrar lo auténtico a través del análisis y de la lúcida comprensión de sí en primer lugar. La identificación de la tierra con su ser, o la inmersión en su recuerdo, ejemplifican este rasgo en Aledo Meloni:

\author{
No lloro el tiempo que muere, \\ lloro el amor que se va; \\ solo envejecemos, sólo, \\ cuando dejamos de amar.
}

(PyC, p.84).

Paul Valéry había dicho que "clásico es el escritor que lleva en sí mismo un crítico y que lo asocia intimamente a sus trabajos". ¿Qué ejemplo más cabal que la incansable tarea de orfebre que ocupa a Meloni permanentemente corrigiendo sus poemas? Con paciencia y minuciosidad pule su lenguaje en una persecución constante de la belleza. Ello se muestra claramente en las sucesivas versiones de sus poemas desde las primeras ediciones hasta el presente.

Continúa H. Peyre: "Emoción y sensación, agitaciones sensuales e impulsos de la imaginación en modo alguno se suprimen en nombre de una 
filosofia altanera y exclusiva. Son admitidos pero gobernados; son comprendidos y analizados y por tanto, afinados y humanizados."

\section{Ella}

Que no me lleve en verano y menos en primavera,

mientras maduran los frutos

mientras la savia anda inquieta.

Que me lleve en el otoño

junto con las hojas secas;

así no me iré tan solo

cuando me vaya con ella.

Que no venga en pleno día, tampoco de madrugada;

que venga a la medianoche para no verle la cara.

Que venga a la medianoche, y entre la sombra de guardia, para no ver lo que dejo cuando con ella me vaya.

(U.S.,p.29).

\section{Cita}

Mediodía de sol, de viento y polvareda.

Desde nuestra memoria una voz nos invita:

es el llamado verde del río y la arboleda; y se nos van los cinco sentidos a la cita.

(PyC,p.110).

\section{Reintegro}

Ya he dicho, vida, la palabra que era mía; ya he bebido tu sol hasta el derroche, te devuelvo la luz, toda la luz y el día: me quedo con la sombra y con la noche. (LOM,p.20)

El espíritu clásico constituye un intento de comprensión del mundo y del hombre; busca en la realidad los indicios significativos, todo puede ser convertido en lenguaje. no tanto para los sentidos como para el intelecto. Lo sensible, lo emocional 
persiste, aunque traducido como experiencia ordenada y sistematizada por el entendimiento.

La literatura es, para Meloni, un instrumento para profundizar su interioridad. La palabra (la imagen) lo conduce por las vias de su ser.

\author{
El oficio de vivir \\ tiene su cábala: \\ hay quien lo aprende cantando, \\ y quien a costa de lágrimas.
}

(PyC,p.119).

Las penas del corazón siempre imaginan caminos: unos llevan al silencio, otros al canto y al vino.

(PyC,p.87).

Coplero soy, alma adentro: una manera de ser; aunque en la copla me encuentro siempre me vuelvo a perder.

Coplero iluso que busca dejar desnuda en la arena, por la suerte de una copla la cicatriz de su huella.

(PyC,p.80).

Peyre asigna otras características a esta mentalidad: impersonalidad y universalidad, refiriéndolas, en el plano semántico, al abordaje de temas que ahondan en la reflexión sobre lo general.

En su dimensión mítica, "el mundo" se compone por la parcela de realidad que está al alcance de la experiencia (sensible, más que intelectual) del hombre. Peyre habla de ausencia de relativismo como uno de los caracteres más destacados del pensamiento clásico. El artista "no niega el color local ni descuida las particularidades individuales." Una actitud fundada en lo intelectual debe tener necesariamente conciencia de aquello que no puede ser objeto de abstracción o generalización.

Ocurre que "los rasgos que asemejan le parecen más llamativos y en todos los sentidos, de mayor consideración y profundidad que los rasgos que los diferencian" (a los seres u objetos). Es ésta la cualidad definitoria de su intención en las coplas: búsqueda de ciertas vendades "universales", de lo permanente tras lo momentáneo y particular.

En este sentido, la poética de Meloni muestra un progresivo despojamiento de lo descriptivo, fundamental en Tierra ceñida a mi costado. El dato sensible se 
convierte en percepción animica y se enriquece con la intuición que constantemente intenta franquear los obstáculos que le impiden ligarse con la humanidad.

$$
\begin{aligned}
& \text { El corazón siempre llora } \\
& \text { cuando recuerda su ayer: } \\
& \text { si triste, por su tristeza; } \\
& \text { si alegre, porque se fue. } \\
& \text { (PyC,p.90). }
\end{aligned}
$$

Como si no le bastara su propia pena, al andar va recogiendo en su alforja las penas de los demás.

(PyC, p.87).

No estoy yo solo en mi copla; en su juego, en su intención están todos los que sienten lo mismo que siento yo.

(PyC, p. 123).

Mi pena es inmemorial, tan antigua como el mundo: nació con el primer hombre y morirá con el último.

$$
\text { (PyC.p.88)., }
$$

"La universalidad parte de una concepción filosófica, la convicción de que hay algo permanente $y$ esencial tras 10 mudable y accidental; de que esta esencia permanente (sustancia) vale más que lo pasajero y relativo."

En lo referido a la temporalidad, una categoría que atraviesa la poética del autor, tanto a nivel estructural profundo como en la textura semántica,se puede aludir a la actitud de "orgullo" fecundo y noble de nuestro autor, que consiste en buscar la trascendencia, en resistirse a lo efímero de todo lo temporal. Podemos agregar que la búsqueda de lo universal reposa en la concepción filosófica enunciada, pero también la aspiración se da merced a una concepción del arte que puede sintetizarse en la máxima "el arte tiene como fin la educación moral de toda la posteridad". Pretende convertirse en modelo, paradigma de la vida, como to proclamaba Montaigne.

Roland Barthes diferencia el texto de placer del texto de goce. El espíritu clásico es el que busca generar una obra que se comprometa con la tradición, que instaure una sensación de familiaridad con el mundo y con el hombre. La estética de Meloni se constituye en una moderada aunque indubitable defensora de las formas que la historia ha legitimado, tanto desde su naturaleza formal como semántica, a pesar de que el poeta diga en "Apariencia": 
La vida en calma deshojo

pero no es como aparenta:

mi alma está siempre en el ojo

de la tormenta.

Ningún halago ya cuenta,

ninguna flor ya recojo:

mi alma está siempre en el ojo

de la tormenta.

(LOM,p.49).

La finalidad de la obra trasciende lo estético y se instala en la vida como voluntad de perduración. La mesura, el equilibrio de su poesía, la compenetración con un humanismo hondamente arraigado en su convicción y que llega a convertirse en un principio de tolerancia y amor al hombre, el deseo manifiesto de expresar los caracteres de la condición humana, constituyen los rasgos claves de una obra que se elabora como correlato de la vida y del mundo y que a la vez los trasciende; cuyo espíritu, pleno de fe en Dios, confianza en la humanidad, pretende traducirse fielmente en la poesia: su grandeza reside en buena parte en la irrevocable búsqueda de la verdad, disipadora de las sombras.

Podemos afirmar, con Henri Peyre, que "alcanza la perfección, única garantia de universalidad, en las aftas regiones en que la verdad y la belleza no se diferencian."

\section{NOTAS}

i Jean Guitton,El trabajo intelectual, , p.43.

ii Alfredo Veiravé, "No hay doencia sin creación", reportaje de Mila Dosso y Julio

Enriquez, en: Norte, Resistencia, 14 de noviembre de 1982, p.19.

iii Marcel Raymond,De Baudelaire al surrealismo p. 300. El crítico alude a la situación planteada por el simbolismo y el surrealismo en cuanto propuesta de ruptura del equilibrio entre el exterior y el interior, en beneficio de éste. El acercamiento a la naturaleza propugnado por los románticos (Goethe) es reivindicado como aspiración en la nueva poesía.

iv Maurice Blanchot, El espacio literario, p. 21.

$\checkmark$ Roman Jakobson, "La dominante". Naturalmente, este concepto antes que cuestionar el de sistema lo afirma: "una obra poética es un sistema estructurado, conjunto regularmente ordenado y jerarquizado de procedimientos artísticos". La 'dominante' garantiza a los estudios literarios la inmanencia de la 'literaturidad' en la obra misma.

vi Aledo Luis Meloni, "Comentario sobre Jorge Luis Borges", in: Norte, Resistencia, domingo 26 de agosto de 1979, p. 14.

vii Antonio Machado, Nota a Gerardo Diego, al publicar una antología de autores españoles, en 1931, in: "Prólogos" de Poesías, pp. 10-12. 
viii Marcel Raymond, op. cit., p. 298.

ix Paul Valéry, N.R.F., $1^{\circ}$ de febrero, 1930. Citado por Marcel Raymond, op. cit., p. 298.

$x$ Especialmente en: L'air et les sognes. Essai sur l'imagination du mouvement, L'eau et les réves.Essai sur l'imagination de la matière, La poétique de la rêvérie y La poétique de l'espace.

$x i$ Phénomenologie de l'experience esthétique.

xii Kostas Axelos, "Kostas Axelos y la trascendencia del pensar", entrevista de Enrique Valiente Noailles.

xiii Lo propio de las ceremonias rituales que conmemoran los ritos consiste en pronunciar las palabras de los textos sagrados, que fueron dichas por los dioses en un principio, durante la creación.

xiv Segundo Serrano Poncela, Antonio Machado, su mundo y su obra.

$x \vee$ Kostas Axelos, artículo citado.

xvi Segundo Serrano Poncela, op. cit., p. 75.

xvii Mircea Eliade, Mito y realidad, p. 20.

xviii En fenomenología, Husserl habla de tres actos: acto expresivo, acto significativo y acto intuitivo, como tres aspectos necesarios de la intuición esencial. El primero, puede vincularse con la sensibilidad; el segundo, con la subjetividad: el objeto (la forma) es "llenada" con los saberes del sujeto, en los que está implícita su valoración de los mismos; el tercero, integrador, es el que indaga el sentido del objeto (la imagen, en este caso).

xix Barthes, Roland, El placer del texto, p. 27. El autor niega al texto la condición de "diálogo", en el sentido de productor de una dialéctica: "ningún riesgo de simulación, de agresión, de chantaje, ninguna rivalidad de idiolectos".

$x x$ Ibid., pp. 16 y 22-23.

xxi luri Tiniánov, El problema de la lengua poética, pp. 55 y ss. Sin dudas, esta interesante y a la postre sumamente difundida tesis se adecuaba al enfoque crítico formalista, basado en la combinatoria del léxico.

xxii Ferdinand de Saussure, Curso de lingüistica general, pp. 207-213. Las relaciones sintagmáticas y paradigmáticas son un aspecto relevante de la lengua. En el Capítulo $\checkmark$ de la Segunda Parte, las caracteriza, las define y proporciona ejemplos de ellas. xxiii Roland Barthes, op. cit., p.14: "Todo escritor dirá entonces: loco no puedo, sano no querría, sólo soy siendo neurótico".

xxiv Ibid., "Texto de placer: el que contenta, colma, da euforia; proviene de la cultura, no rompe con ella y está ligado a una práctica confortable de la lectura."

xxv Octavio Paz, El arco y la lira pp. 135-136. Podemos completar la idea con otro párrafo del autor: "...en la experiencia de lo sobrenatural como en la del amor y en la poesía, el hombre se siente arrancado o separado de sí. Y a esta primera sensación de ruptura sucede otra de total identificación con aquello que nos parecia ajeno y al cual nos hemos fundido de tal modo que ya es indistinguible e inseparable de nuestro ser."

XXvi Maurice Blanchot, El espacio literario, pp. 243-245.

xxvii Octavio Paz, El arco y la lira, pp. 269-270.

xxviii Ibid., p.178. 
xxix Paul Hazard, La crisis de la conciencia europea. Ver especialmente el Capitulo Primero: "De la estabilidad al movimiento", pp. 1-27.

xxx Adolfina Mondín, artículo citado.

xxxi Entrevista personal con el autor.

xxxii Paul Hazard, op. cit., p. 3

xxxiii 'Paul Hazard, op. cit., pp. 45-46.

xxxiv Henri Peyre, ¿Qué es el clasicismo? Ver el capítulo "Caracteres generales del clasicismo francés."

\section{BIBLIOGRAFÍA BÁSICA}

-AGUIAR E SILVA, Víctor Manuel (1972), Teoria de la literatura, Madrid, Gredos.

-AXELOS, Kostas (1986), "Kostas Axelos y la trascendencia del pensar", entrevista de Enrique Valiente Noailles, in: La Nación, Bs. As., 20 de abril de 1986, sección 4a., p.2. -BACHELARD, Gastón (1942), L'eau et les rêves. Essai sur l'imagination de la matiére, Paris, Jose Corti. Trad.: El agua y los sueños. Ensayo sobre la imaginación de la materia. México, F.C.E., 1978, Trad. Ida Vitale.

(1950), L'air et les songes. Essai sur l'imagination du

mouvement Paris, Jose Corti. Trad.: El aire y los sueños. Ensayo sobre la imaginación del movimiento, México, F.C.E., 1980, Trad. Ernestina de Champourcin. - (1960), La poétique de la revérie, Paris, Presses Universitaires de France. Trad. La poética de la ensoñación, México, F.C.E., 1983, Trad. Ida Vitale. (1957), La poétique de l'espace Paris, Presses Universitaires de France. Trad. La poética del espacio, México, F.C.E., 1983, Trad. Ernestina de Champourcin.

-BAJTIN, Mijail M. (1985) Estética de la reación verbal, México, Siglo XXI, $2 a$. Edición.

-BARTHES, Roland (1986), El placer del texto y la lección inaugural, México, Siglo $X X I, 3 a$. Edición ampliada. (1971) "El discurso de la historia", in: BARTHES, R., y otros, Ensayos estructuralistas, Bs. As., Centro Editor.

-BLANCHOT, Maurice (1969) El espacio literario, Bs. As., Paidós.

-CASTAGNINO, Raúl (1980), Fenomenologia de lo poético, Bs.As., Plus Ultra.

-De MAN, Paul, (1990) Alegorías de la lectura, Madrid, Lumen.

-DI GIROLAMO, Costanzo (1982), Teoría Crítica de la Literatura, Barcelona, Crítica. Trad. Alejandro Pérez.

-COHEN, Jean (1977), Estructura del lenguaje poético, Madrid, Gredos, trad. Martín Blanco Alvarez.

-DUFRENNE, Mikel (1970), Phénomenologie de l'experience esthétique, Paris, P.U.F., T. II.

-ECO, Umberto (1979), Obra abierta, Barcelona, Ariel.

(1980), Lector in fabula, Barcelona, Lumen.

(1985), Tratado de semiótica general, Barcelona, Lumen. 
-ELIADE, Mircea (1963), Aspects du mythe, Paris, Gallimard. Trad. Mito y realidad, Madrid, Guadarrama, 1973, Trad. Luis Gil.

-ERLICH, Victor (1974), El formalismo ruso, Barcelona, Seix Barral.

-GIRAUD, Pierre (1971), "El campo estilistico del 'abismo' de Baudelaire", in Sörensen, Hans, y otros, Tres enfoques de la literatura, Bs. As., Centro Editor.

-HAZARD, Paul (1975), La crisis de la conciencia europea, Madrid, Pegaso.

JAKOBSON, Roman (1973), Questions de poétique, Paris, Seuil. (1984), Ensayos de lingüistica general, Barcelona, Ariel. (1980), Dialoques, Paris, Flammarion.

-JAUSS, Hans Robert (1981), "Estética de la recepción y comunicación literaria", in: Punto de vista, Año 13, № 142, julio-octubre 1981.

-MACHADO, Antonio (1973), "Prólogos", in: Poesias, Bs. As., Losada. (1973), Juan de Mairena I, Bs. As., Losada. (1973), Juan de Mairena II, Bs. As., Losada.

-MARTINEZ BONATTI, Félix (1972), La estructura de la obra literaria, Bs. As., Seix Barral.

-MELONI, Aledo Luis (1979), "Comentario sobre Jorge Luis Borges", in: Norte, Resistencia, domingo 26 de agosto, p.14.

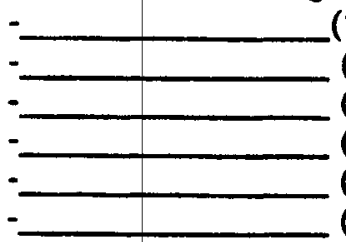
(1980), Poemas y coplas, Resistencia, Moro. (1984), Umbral del silencio, Resistencia, Moro. (1987), La luz que uno amaba, Resistencia, Moro. (1992), La otra mirada, Resistencia, Moro. (1993), Poesía, Resistencia, Meana \& Meana. (1995), Leve fulgor, Resistencia, Meana \& Meana. (1997), Todo se vuelve azul, Resistencia, Meana \& Meana.

-MENENDEZ PIDAL, Ramón (1956), El romancero tradicional español, Madrid, Espasa-Calpe.

-MIRANDA, Guido (1973), Al norte del paralelo 28, Resistencia, Región. (1980), Tres ciclos chaqueños, Resistencia, Norte Argentino. (1979), "La rosa étnica del Chaco", in: Sociológica, Revista Argentina de Ciencias Sociales, № 2/3, Buenos Aires. (1975), El paisaie Chaqueño, Resistencia, Región.

-MOLINA, Gerardo (1978), La versificación española, Montevideo, Ed. Vinaak. -MONDIN, Adolfina (1979), "Aledo Luis Meloni: La costumbre del canto", in: La Prensa, Bs. As., $1^{\circ}$ de septiembre de 1979.

-PAZ, Octavio (1983), El arco y la lira, México, F.C.E..

-PEYRE, Henri (1965), ¿Qué es el clasicismo?, México, F.C.E.

-PIACENTINI, Carlos Primo (1979), Historia de la Provincia del Chaco. Chaco territorial y Chaco Provincia, Resistencia, Región, T.V.

-RAYMOND, Marcel (1933), De Baudelaire au surréalisme, Paris, Jose Corti. Trad. De Baudelaire al surrealismo, México, F.C.E., 1983.

-RICCI, Serafín F. (1983), "Umbral del silencio", in: Heraldo Azul, Charata, Chaco, Año I, nº 1, Agosto, 1983.

-SAUSSURE. Férdinand de (1972), Curso de Lingüistica general, Bs. As., Losada. 
-SANTAYANA, George (1969), Tres poetas filósofos: Lucrecio, Dante, Goethe, Bs. As., Losada, 3a. Ed. en cast. Trad. José Ferrater Mora.

-SERRANO PONCELA, Segundo (1954), Antonio Machado, su mundo y su obra, Bs. As.

-TINIANOV, luri (1972), El problema de la lengua poética, México, Siglo XXI.

-VALESINI, Aldo Oscar (1989), "Lectura de un poema de Aledo Luis Meloni y sus variantes", in: Cuadernos de Literatura No 4, Resistencia, Chaco, Facultad de Humanidades, pp. 167-177.

-VAZQUEZ de BORONAT, Dalmira (1997), "Aledo Luis Meloni", ensayo inédito.

-VEIRAVE, Alfredo (1982), "No hay docencia sin creación", reportaje de Mila Dosso y Julio Enríquez, in: Norte, Resistencia, 14 de noviembre, p. 19.

-VERDUGO, Iber (1982), Hacia el conocimiento del poema, Bs. As., Hachette.

-WELLEK, René y WARREN, Austin (1959), Teoría literaria, Madrid, Gredos.

-ZÉRAFFA, Michel Novela y sociedad, (1978), Bs. As., Amorrortu.

Nota aclaratoria: En la ejemplificación usada se utilizan las abreviaturas "PyC", "U.S.", "LL...." , "AN", "LOM" y "T.A." para nombrar los libros: Poemas y Coplas, Umbral del silencio, La luz que uno amaba, Antes que sea noche La otra mirada y Todo se vuelve azul, respectivamente, según la edición citada en esta bibliografía. 